\title{
Network Capital: Emigration From Hong Kong
}

\author{
by \\ Siu-lun Wong \\ Centre of Asian Studies \\ The University of Hong Kong \\ and \\ Janet W. Salaff \\ Department of Sociology \\ The University of Toronto
}

\author{
Total Word Length : 7,833 Words \\ (including abstract, text, notes and bibliography) \\ Last checked/updated on 11 July 1997
}

Please direct correspondence to Professor S.L. Wong, Centre of Asian Studies, The University of Hong Kong, Pokfulam Road, Hong Kong. Telephone: 852-2859 2465; Fax: 852-2559 5884. 


\title{
Network Capital: Emigration From Hong Kong
}

\author{
ABSTRACT \\ In this paper, we argue that it would be fruitful to regard personal networks as a form \\ of capital capable of generating economic returns by drawing on our research findings on the \\ recent wave of emigration from Hong Kong. By putting network capital on a par with \\ economic and cultural capital, we seek to identify its distinctive features in terms of \\ institutionalization, capacity, moral economy, and processes of conversion and reproduction. \\ In substantiating our argument, we present some quantitative evidence from our survey data \\ on the uneven distribution of kinship ties which can be mobilized for emigration among \\ different occupational classes. We then make use of our in-depth interview data to show that \\ there is a qualitative variation too in the type of networks used by different occupational \\ classes for emigration purposes. We conclude by reflecting on the implications of the \\ concept of network capital for the study of migration, class formation, and the global \\ economy.
}

Key Words: personal networks, emigration decisions, class situations 


\section{Network Capital: Emigration From Hong Kong ${ }^{1}$}

Personal networks are useful but elusive assets. ${ }^{2}$ Individuals rely on them for contacts in seeking jobs and other opportunities, for quick assistance when they are under pressure, for daily needs such as child-care and other practical help, and for emotional support (see e.g. Granovetter 1974; Grieco 1987; Wellman and Wortley 1990; Poel 1993). Like people in other societies, the Chinese value networks and devote much attention to the cultivation of personal bonds which they call guanxi [kuan-hsi]. The importance attached to guanxi by the Chinese is well recognized by scholars. The systematic study by Ambrose King on this topic can be taken as representative. He points out that 'network building is used (consciously or unconsciously) by Chinese adults as a cultural strategy in mobilizing social resources for goal attainment in various spheres of social life' (King 1991: 79. See also Smart 1993; Yang 1994). However, his main concern is with the cultural logic of network building, and he has not attended to the uneven distribution of guanxi as a resource within Chinese society.

Networks affect decisions about major changes in life events, such as the decision to emigrate. How Chinese families draw upon networks when they relocate themselves is an important area of research. From the vantage point of emigration, we can develop a differentiated model of emigrant networks. A study of the emigration decisions of Hong Kong Chinese is an excellent place to begin, because Hong Kong emigrants come from diverse social backgrounds. In this paper, we shall compare how working and middle classes, who structure their personal networks differently, use their contacts and connections when they decide to move across the seas. Our findings suggest that it would be fruitful to regard networks as a form of capital, that is, an asset 'capable of conferring strength, power and consequently profit on their holder' (Bourdieu 1987: 4; see also Bottomore 1983: 60-4). 
This paper is divided into three parts. In the first part, we outline the major findings of our research on emigration from Hong Kong and develop the notion of network capital. In the second part, we present in more detail the quantitative evidence on how networks affect migration decisions of different occupational groupings by drawing on our survey data. Then in the third part, we make use of our qualitative interview data to discuss and to illustrate how potential migrants from a range of socioeconomic backgrounds perceive the role of networks in their emigration decisions.

\section{NETWORK CAPITAL}

In our research, we discover three significant features in the use of personal networks for emigration purposes in Hong Kong. First, there is a quantitative variation in terms of occupational class. ${ }^{3}$ On the whole, the higher the class position of the family, the larger the number of social ties which can be mobilized for emigration. Options increase as one moves up the social ladder. Second, there is a qualitative variation too in the type of networks used by members of different occupational classes. Working class emigrants tend to depend heavily on family and kinship ties, while affluent emigrants are more inclined to activate diverse bonds of friendship. Third, members of the lower middle class, whose livelihood hinges on bureaucratic careers and wages, have the lowest emigration propensity. It seems that the assets they possess are the least mobile and transferable.

These findings suggest that it may be fruitful to regard networks as a form of capital. This idea is akin to the concept of social capital as proposed by scholars such as Pierre Bourdieu and James Coleman. But Bourdieu (1987: 4) refers to social capital as 'resources based on connections and group membership' without further elaboration. Coleman (1988: S95), pursuing a different theoretical objective, uses the concept in a wide sense to include 
obligations and expectations, information channels, and social norms. Here we are confining ourselves more specifically to the mobilization of personal networks to generate economic returns. By putting forth the notion of network capital, we are trying to elaborate on Bourdieu's idea and relate quanxi and connections directly to the question of social inequality and class formation (for another elaboration on Bourdieu's idea, see Erickson 1996). When network capital is put on a par with other forms of capital, such as economic and cultural capital, we may come to a better appreciation of the diversity and fluidity in the class structure of a Chinese community such as Hong Kong. It would also lead us to identify at least three analytically distinct class situations which correspond to the three forms of capital, namely the entrepreneurs with networks as asset, the capitalists with economic means of production as property, and the professionals with knowledge and skill as resource. ${ }^{4}$ These class situations are of course only theoretical constructions or ideal types. In reality, they tend to overlap and seldom exist in the pure form.

\section{$\underline{\text { Institutionalization }}$}

In comparison with economic and cultural capital, network capital is the least institutionalized form of asset. On the whole, economic capital is institutionalized in the form of property rights, and cultural capital in the form of educational qualifications (Bourdieu 1986: 243). Both forms depend heavily on the reliability of social institutions or system trust. Network capital, on the other hand, is basically a diffused asset. It may sometimes take the institutional form of associations of various kinds, but it is generally lodged in reciprocal relations that may or may not be upheld by the parties concerned. In order to reduce uncertainty and to reinforce mutual obligations, personal trust plays a more prominent role as a cementing force in the accumulation of network capital. Therefore, rela- 
tively speaking, network capital is less dependent on system trust though it can never be completely free of this form of trust as resources such as classmate networks are derived from reliable educational institutions. (On the distinction between personal and system trust, see Luhmann 1979; Wong 1991).

Because of the different degrees of institutionalization, the three forms of capital tend to have distinctive patterns of geographical mobility and would be drawn to different destinations. The movement of economic capital would typically follow the logic of comparative advantage. In the case of Hong Kong, for example, industrialists in the cotton spinning sector had a tendency to diversify their investments into Southeast Asia, Latin America and parts of Africa where labour costs were relatively low and textile quotas were available (Wong 1988: 39).

The movement of cultural capital is affected by the recognition of credentials and the compatibility in educational systems in host countries. Consequently, as revealed in our study, the most popular destinations for the present wave of educated migrants from Hong Kong are English speaking countries such as Canada, the United States, and Australia.

Network capital, being less dependent on system trust, has a greater scope for diffusion and a better ability to transcend boundaries. It tends to spread with the Chinese Diaspora through personal connections. It can venture into territories with shaky institutional frameworks for business operations, such as the People's Republic of China and Vietnam, and still manage to flourish (see Smart and Smart 1991; Sung 1992; Wong 1995). 


\section{Network Capacity}

After contrasting network capital with other forms of capital, it is necessary to examine the heterogeneous nature of personal networks and its implications more closely. Different types of personal bonds exist, with various capacities in facilitating mobility and economic competition. There are kin and non-kin ties, and there are strong and weak linkages (Granovetter 1982). In our study, we have found that reliance on kin ties and strong linkages are more characteristic of the working class. For members of the affluent class, they are actually disinclined to make use of such ties and often refuse help from family members and relatives.

It is our hypothesis that there exist a restricted and elaborated style of network construction among our respondents. Dependence on kin relations and strong ties is the hallmark of the restricted network style, and flexible use of non-kin relations and weak ties is the key feature of the elaborated network style. An elaborated network style is useful in economic competition because it generates greater access to sources of information and provides more autonomy for action. It can create networks rich in 'structural holes', that is, networks with relationships of low redundancy. Ronald Burt (1992: 21) asserts that such 'optimized' networks have two design principles. The first is efficiency, achieved by concentrating on the primary contact and allowing relationship with others in the cluster to weaken into indirect relations. Second is effectiveness, attained through differentiating primary from secondary contacts in order to focus resources on preserving the former. 


\section{Moral Economy}

The 'design' principles as set out by Burt alert us to what may be called the moral economy of network capital. In the attempt to optimize benefits, individuals would have to be calculative in manipulating relations to their favour. Granovetter seems to be conscious of this moral ambivalence inherent in network construction when he states wryly, 'Lest readers of SWT [Strength of Weak Ties] and this chapter ditch all their close friends and set out to construct large networks of acquaintances, I had better say that strong ties can also have some value.' (1982: 113; see also Burt 1992: 262).

This defensive statement reveals the basic reason why those who are skilled at networking, such as entrepreneurs, tend to incur popular hostility and resentment in a society (see Yang 1994: 51-64; Chu and Ju 1993: 133-4; 150-3). They would appear to be too cunning and pragmatic. They spurn the sacredness of personal relations, turning ends into means. Thus they are open to charges of undermining social solidarity and eroding group allegiance. These are the dark sides of network capital.

\section{Conversion and Reproduction}

Another source of hostility towards network construction can be traced to the sites of tension with other forms of capital, especially with cultural capital. In Hong Kong society, studies have shown that people tend to seek advancement through two major channels of mobility: the entrepreneurial route of starting one's own business, and the credential route of acquiring professional qualifications (T.W.P. Wong 1991: 164-5). Both network capital and cultural capital are apparently valued and sought after. Yet other studies have revealed a strong anti-capitalist sentiment and deep distrust of entrepreneurs among the educated 
professionals (S.L.Wong 1994: 230-2). Evidently friction and rivalry exist between carriers of network and cultural capital.

Such a tension draws our attention to the problem of conversion and reproduction of various forms of capital. The conversion of cultural capital into network capital in the process of migration is relatively well documented by now. Research on small factory owners in Hong Kong has found that many of these entrepreneurs were immigrants from China with high educational attainment. But their credentials were not recognized in Hong Kong, thus forcing them to seek advancement through industrial endeavours instead (Sit and Wong 1989: 97-100). In the present wave of emigration from Hong Kong, the educated professionals are facing a similar barrier overseas where their qualifications and experience are not fully recognized. A substantial number of them are thus turning themselves into entrepreneurs by setting up small businesses in destination countries such as Australia (see Lever-Tracy et al. 1991).

However, the direction of conversion is by no means one way only. We have found that there is nearly a universal concern expressed by our respondents for their children's education. Hong Kong Chinese entrepreneurs, whether potential or actual, share with others the same preoccupation with the cultivation of cultural capital for themselves and among their offspring (see Ong 1992). Thus there appears to exist a cyclical process of intergenerational conversion of network into cultural capital and vice versa. But how precisely is network capital reproduced in the family and passed through the generations? What role does gender play in particular in the accumulation and transmission of this type of capital? We know very little about these issues and clearly more research is needed. The study of emigration from Hong Kong, as we attempt to show in the following sections, should provide a good vantage point in scrutinizing the multifarious features of network capital. 


\section{EMIGRATION DECISIONS AND KIN NETWORKS}

\section{$\underline{\text { The Setting }}$}

Situated at the mouth of the Pearl River delta in southern China, Hong Kong had long been a city of migrants with massive outflow and inflow of people. Before the Second World War, Hong Kong served as the major port for the Chinese living in Guangdong and other provinces to venture abroad (Sinn 1995). Following the Chinese Communist victory in 1949, over one million refugees left the mainland and sought shelter in the territory. Some brought machinery and know-how from Shanghai and other Chinese coastal cities, and formed a local entrepreneurial class that mainly produced textiles to start the industrialization there (Wong 1988). Others became low-cost labour. With the influx of these immigrants of diverse social backgrounds, Hong Kong transformed itself from an entrepot into a manufacturing centre.

As sojourners in their own city, Hong Kong people move readily to places where they can find work. The first wave of emigrants were mainly poor. The Western economies drew on unskilled immigrant workers, and Great Britain had not yet set up barriers to Commonwealth members. Poorly educated New Territories village men left in large numbers to open and work in restaurants in Great British (Watson 1975). Gradually, the skills of those who went abroad changed. As Hong Kong society developed a strong middle class tied intellectually to Western nations, many sent their children abroad to study. The students often remained, and these links prompted more people to go back and forth. In the 1980s, Western immigration policies favoured young, well educated, English-speaking professionals, technicians and managers with financial means (Skeldon 1990-1; Kwong 1991). 
More recently, in response to Hong Kong's anticipated reversion to China in 1997, many have applied to emigrate abroad (Wong 1992; Salaff and Wong 1994). Since 1989, about 60,000 Hong Kong Chinese emigrated annually, with Canada, the United States, and Australia as the main destinations. But we find that while political concerns are widespread, connections not attitudes determine who plan to exit and where they go. Emigrants activate their personal networks to leave Hong Kong.

\section{Source of Data}

We begin with survey data on kin networks and their association with the emigration decisions of people from different occupational classes. The statistical data come from a survey of 1552 Hong Kong respondents conducted in Hong Kong in 1991. The year after the survey, we chose 30 respondents from the sample for an in-depth analysis of how social ties affect the emigration decisions of their families, and talked with them at length several times from 1992 through 1997. The qualitative interviews went further than the survey questionnaire and located the wider kin circles, friends and colleagues of both husband and wife that applied to emigrate. We obtained these respondents' views of the importance of networks in emigrating, and how these networks entered in their plans. (For details about the survey and the interviews, see Skeldon 1995)

In the table based on the survey findings, we divided the respondents into four major groups according to occupation. For the convenience of presentation, we referred to them as different classes in common sense terms. The affluent class included managers and professionals. Then there were the small businessmen making up the petty bourgeois class. The lower middle class consisted mainly of white-collar workers. Finally, the working class 
was composed of manual and seasonal workers. We classified our married respondents' families by the highest occupation of either spouse.

In choosing the families for our qualitative study, we sought to interview equal numbers of emigrant and non-emigrant families. An emigrant family is one in which any member has actually submitted an immigration application form to a foreign country. But this is used only as a convenient operational definition, because in reality the situation is very complex and the distinction between emigrant and non-emigrant families is far from clear cut. Many families in Hong Kong are in fact what Myron Cohen (1970) has called 'dispersed' families with members and relatives already living abroad yet still maintaining a shared economy.

We tried to match the emigrant and non-emigrant families by occupational background, ranging from the administrators to the manual workers. In our discussion of these families, because of the small number of cases, we reduced the occupational class classification from four to three. We did not classify the petty bourgeoisie as a separate category. Rather, since we had a lot of information about the qualitative sample, it enabled us to place the families of the small businessmen into either the lower middle class or the affluent class as appropriate.

\section{Survey Findings}

Many Hong Kong families have kin abroad. In table 1, we can see that the 1552 respondents in the survey have an average of about 0.67 to 0.38 family members abroad, depending on their class background. The working class has the fewest family members abroad and the affluent class has the most. On the whole, those that plan to emigrate have twice as many kin overseas as those that do not plan to leave. 
When we look at the differences among the class groups, we find a trend. Emigrants in three of the four class groups have more kinship ties overseas than do non-emigrant households. We find the most dramatic difference in the number of kinship ties between emigrant and non-emigrant households in the working class. The petty bourgeois businessmen, mainly with family businesses, follow. The lower middle class shows a small difference, while the affluent class actually reverses the trend.

[Table 1 here]

However, the survey questions did not ask how kinship ties actually affect the emigration decisions. Ties of friendship and acquaintance were not covered. Further, the survey collected only limited data about the family as a unit. For instance, the survey asked questions about the number of the respondent's family members abroad, but not specifically about those of their spouse's kin. To address such questions, we have to turn to the in-depth interviews.

\section{SOCIAL NETWORKS AND FAMILY STRATEGIES}

Among the families that we interviewed over time, those who had applied to emigrate had more emigrant siblings than the non-emigrants (see Table 2). In addition, we asked emigrant applicants if they had other friends and colleagues that had already gone abroad. We 
Table 1

Average Kinship Ties of Survey Respondents by Emigration Status and Class

Class

Average Number of Kin Living Abroad

Emigrant Non-emigrant Average

$\begin{array}{lccc}\text { Affluent } & 0.61 & 0.87 & 0.67 \\ \text { Petty bourgeois } & 0.69 & 0.54 & 0.56 \\ \text { Lower middle } & 0.53 & 0.50 & 0.50 \\ \text { Working } & 0.72 & 0.36 & 0.38\end{array}$

Source: 1991 Emigration Survey 
expected that having emigrant friends would also propel our respondents to emigrate. Those with friends and colleagues who had already emigrated could count on them for help or tips about life abroad. Those with friends that were applying could form a reference group of like minded people, who would influence each other that it was a right decision to exit. Other factors such as family size and family life cycle may also affect the propensity to emigrate, but we shall not delve into them in this paper.

[Table 2 here] 


\section{Table 2}

Emigrant Kin of Emigrants and Non-emigrants

Respondents

Emigrant Siblings as \% of Total No. of Siblings

$\underline{\text { Emigrants }}$

Working class

$36 \%$

Lower middle class

$46 \%$

Affluent class

$33 \%$

$\underline{\text { Non-emigrants }}$

Working class

$12 \%$

Lower middle class

$15 \%$

Affluent class

$27 \%$

$\underline{\text { Total }}$

Working class

$24 \%$

Lower middle class

$24 \%$

Affluent class

$46 \%$

Source: Interviews 1992-1997 
We found that friends were important to future emigrants: 13 of the 16 applicants had friends, neighbours, or co-workers that had emigrated and with whom they kept in touch. In contrast, non-emigrants did not keep in touch with acquaintances abroad. Indeed, few could think of any close friends who had emigrated. These suggestive finding, taken together with our survey material on a larger sample of Hong Kong respondents, highlights the importance of looking further into the relations abroad of emigrant and non-emigrant families. In the following analysis of our case materials, we assume the existence of a coherent emigration strategy for each family though we are aware that individual strategies may collide with the family strategy and that individual family members do not necessary share the same views and uphold the same decisions. In our interviews with the families, we tried to obtain the views of both spouses. But since husbands are expected to play the public role as heads of household in Hong Kong, the adult male views are often more vocal.

\section{Working Class Families}

In Table 1, we find that emigrant working class families have almost double the number of kinship ties of non-emigrant working class families. Our in-depth interviews confirm the survey findings. Working class families emigrate with an eye to those kin who have already left. Their ties to kin run deep even while they live in Hong Kong. Kin assistance is widespread and multi-stranded among these working class Chinese.

Given the many ties of assistance among the working class in Hong Kong, we can understand why emigrants follow kin abroad. We interviewed 10 working class families, of whom four had applied to emigrate. Three sought to emigrate through kin support. Some started with complete dependence. One route for folks without wealth is emigration through 
joint family action. To even think of emigrating, their close kin have to help them to find jobs.

Having kin abroad not only helps people to find a job, it also provides practical help to emigrate. Siblings and in-laws may buy homes together in the new country. Or, they may put together an investment package to qualify for a visa. For instance, we spoke with a parttime restaurant helper, married to a truck driver, and the mother of two teenage daughters and an autistic son. Her older brother sponsored her for an American visa, and offered her a job. Family reunification was the legal basis for their application. Further, she could only consider emigration because she expected to find work in her brother's Boston restaurant. As she recounted, so had others in her family before her:

'By working in the kitchen of Brother's restaurant, Father earned more than US $\$ 1,000$ dollars a month. He said that he could earn as much in one month as he could working in China for several years! But now he is old. He does not work any more... Altogether, we are six brothers and sisters, and I'm the youngest. All have applied to go to the United States. My third sister is most enthusiastic about emigrating. She is a housewife and her husband works in a Chinese restaurant here in Hong Kong. They have money. My elder brother said he would help her buy a house to prepare for her coming. He'll rent it out until she arrives.'

Few working-class families have ever lived outside of Hong Kong or the Chinese mainland. They have little first hand experience of other places. They closely depend on those they know in foreign lands to give them information about life abroad. In most cases, these are kin. Those working class folks we met who applied to emigrate applied to just one country. This was largely because they could count on kin support in only one place. 
Echoing the survey results, we found in our interviews that working class nonemigrants tended to have fewer kin overseas than the emigrants. Yet there were still many non-emigrants who did have siblings abroad. When we asked those with siblings abroad why they decided not to follow them, their answers were mainly that they did not have enough money and their siblings could not offer them work.

We expected that having emigrant friends would also propel our respondents to emigrate. But we found that working class folks did not get the chance to emigrate from friends. While they might find comfort in learning about the plans of their work-mates and acquaintances, they could not lean too heavily on these contacts. Their friends, who had jobs like theirs, were not able to give them a job that was good enough to warrant emigrating, or one that would get them a visa. Further, these working class friends had their own kin to support.

A young clerk in a dry cleaning store, married to a bank messenger, told us of her novel way to contact a former neighbour and a former co-worker in Toronto and San Francisco. In the Christmas of 1992, she used the fax machine in the store to send greetings to these friends. 'It's unusual, and it only costs 10 [Hong Kong] dollars!' But she felt, 'We can't depend on our friends to emigrate. Actually, I don't like San Francisco very much. So I think I'd travel there, but not settle down. You know, it is difficult to find a job over there and we have few relatives and friends who could take care of us.'

In sum, dense ties provide a link to the job, which is a necessity to working class emigrants. Most have dense ties only to kin. Migrant kin that already have a foothold abroad may have opened small businesses serving the ethnic community (Zhou 1992). If they feel obliged to offer their close kin jobs, these relatives can join them. We believe that this is one of the few ways the working class families can succeed in emigrating. For without jobs in 
the working class community, they have little chance to survive in the distant world, that is currently in recession, and whose language they speak only poorly.

\section{$\underline{\text { Lower Middle Class Families }}$}

Our study contains 10 lower middle class couples. Most worked in bureaucracies in the public and private sectors. Four families had applied to emigrate. The way they applied was distinctive, for while lower middle class emigrants had kin abroad, they were less likely to draw on these kin to emigrate. None applied for family reunification. Their main strategy was to take advantage of their civil service status to apply as special emigrants to Singapore or England. A civil servant, a former policeman, and a teacher pursued this option. Kinship connections did not help them.

The reason that few used kin ties to emigrate was not because they had none. In Tables 1 and 2, we find that they did have emigrant kin. Rather, the nature of their family economies were separate from kin. The lower middle class cannot depend on kin to emigrate because the kinds of jobs they hold are not obtained through kin. They secure their livelihood on the basis of the cultural capital at their disposal, in the form of achieved qualifications obtained through advanced study and legitimated by diplomas. These nurses, technicians, civil servants, assistant engineers and school teachers earn good salaries and can look forward to promotions through fixed steps on career ladders.

These lower middle class workers are not particularly keen to emigrate for a number of reasons. First, they cannot count on getting similar jobs abroad. Some work for the Hong Kong government and other public bodies, and they cannot qualify for this kind of work elsewhere. None have the necessary licenses or certification to start again in their lines of work overseas. Second, they earn too little for most investment categories of immigrants. 
They also lack the higher education or specialized training to qualify as 'other independent' emigrants to Canada and Australia, the countries to which most Hong Kong people seek to enter. Third, they have enjoyed a spurt of income improvement in recent years, which they fear they cannot match abroad. Partly this is because both spouses work to maintain a dualincome household economy. With few grand economic hopes for themselves, they are not eager to reject the solid living standard they enjoy for an uncertain life abroad.

Only one of these lower middle class couples used its kinship ties in an application to emigrate, but failed. Unable to get jobs in their line of work from kin, the lower middle class use other channels. A civil servant status helps the most. Singapore and England remain options for those that have quasi-political civil service jobs. We interviewed a woman who was a clerk in the correctional services, married to a man now in England, who had been a constable. As a young man, her husband had studied karate in his uncle's martial arts studio. He then studied with the instructor of the world famous martial artist Bruce Lee, became proficient, and began to teach in a community center. He joined the police force. While at a training course, he met a British constable, also an admirer of Bruce Lee, who had come to Hong Kong to meet Lee's coach and train with him. In early 1989, the British constable invited him to Manchester to teach karate, and arranged for him to have working papers.

This couple combined channels of help from friends, kin, and the government bureaucracy. The husband had been close to his kin in Hong Kong. He received concrete help in finding work abroad from a colleague. But they took the crucial emigration step through the wife's civil service connection. In the wake of the June Fourth incident in 1989, the constable became afraid of remaining in Hong Kong. As a member of the correctional services, his wife qualified for the British Nationality Scheme for herself, with eligibility extended to her immediate family. She and their son had emigrated to Manchester to join her husband. 
Those who have no kin abroad are reluctant to exit. But even with kin abroad, those holding modest salaried posts may not join them. They worry that they cannot easily fit into an enterprise that their foreign kin might run. If the work relationship falters, they will be left without a base of their own and will have no economic recourse. Indeed, these lower middle class workers pride themselves on being independent.

A land inspector in the Hong Kong civil service, married to a part-time sewing operator, decided not to emigrate even though his sister's daughter asked them to join her family in moving to Australia and offered him a job in the firm her family hoped to open:

'I tell my niece I won't go. Her husband is a professor of pharmacy in the

United States. He is doing some research and patented a new medicine. They are very rich. They want to set up a pharmacy shop in Australia, and ask me to go there to do some clerical job. But I don't want to rely on my relatives. I am independent. I never seek help from others.'

\section{$\underline{\text { Affluent Families }}$}

In Table 1 above, we find that while the affluent families have more kin abroad than any other group, those that emigrate do not have more kin than non-emigrants. Indeed, the relationship is reversed. This points to a phenomenon that is worth exploring: that the affluent class does not depend on kin to emigrate as much as do the working class.

The affluent class includes businessmen and professionals. Two of the ten we interviewed worked with kin in flourishing family firms. The rest had little occupational contact with kin. Regardless of whether they worked closely with kin or not, they sought emigration in similar ways. 
Eight of the ten affluent families we interviewed were emigrants in a technical sense, because they already had visas to exit Hong Kong. However, they told us that they did not intend to use them unless 1997 precipitated a crisis. Their visas were for 'insurance purposes'. Several had the option to emigrate to more than one country. Only one, an unmarried member of a family that had members living in Alberta, was granted a visa in the family reunification category. The rest applied to emigrate under the business or 'other independent' categories, or as civil servants under the British Nationality Scheme. While several of these affluent respondents had visas to places where they had kin, they were not economically dependent on these relatives. Instead, they were more likely to stress their networks of schoolmates and former colleagues.

It is true that well placed kin living abroad can offer positions to those they sponsor. But our affluent respondents did not depend on these jobs. To be sure, some used the offer of a convenient 'paper' job to satisfy the requirements of the emigration authorities. They did not actually expect to take up the jobs so offered.

The kinship contacts of these affluent couples are neither spatially nor socially concentrated, but are spread out. Most have emigrant kin in many different countries. Their relatives are more widely placed around the globe than those of the working class. They are not tied tightly to their kin contacts, as they have other network resources. Here, friends, colleagues, and classmates are crucial.

A site engineer, who received his diploma in the Hong Kong Polytechnic after six years of part-time study, was employed by a large Hong Kong construction firm. On the side, he had opened a small interior design firm with his classmates as shareholders. Yet another Polytechnic classmate emigrated to Vancouver: 'I bought my Richmond house there with his help. I never even went there; he helped me care for it. My classmate told me not to 
emigrate because the economy for construction was so bad. But if I do emigrate, I'll probably work with him at the start.'

Affluent emigrants feel these emigrant friends are important, and they sometimes are more important than emigrant kin. Depending on classmates for help is common for our affluent respondents. Friends are already established and can give the newcomer a first job. The job can be permanent, or if it does not work out, it provides a temporary shelter while the new immigrant settles in and learns the ropes. Or, in the same trade, the classmate can give the newcomer information that leads to a job.

The managing director of a printing company had got visas from several countries. His sister was living in Canada, but he excluded that country as an emigration possibility. 'It's too far for our children to travel there, and we don't like the climate,' his wife said. 'If we haven't even bothered to visit her in Toronto, how could we want to live there?' They chose Singapore as their emigration destination. There, the managing director had many classmates and business associates. Singapore is also closer than Toronto to their China based business. They had already bought a house there, as part of their emigration plan. Another of the managing director's brothers would emigrate to Singapore as a teacher, but he claimed he was not influenced by this relation. He chose to apply for Singapore papers because it had more flexible emigration conditions, and because his classmates who were there could help him work out his business arrangements.

When affluent individuals describe working with former classmates, it is clear they are thinking of an egalitarian relationship. They do not feel that by agreeing to work together, they are depending on friends. It is understood that each side is ready to put up capital. Their classmates know one another's skills and talents. Such a relationship with friends does not make them feel like they are getting a handout. For this reason, many potential emigrants from the affluent class prefer to rely on friends than kin. 


\section{CONCLUSION}

Emigration is a selective and transformative process. People mobilize diverse forms of resources to move from place to place. As their assets and endowments vary, they make up different types of migrants. Our findings suggest that future analyses of international migration should distinguish between not only rich and poor, literate and illiterate migrants, but also migrants with disparate network capacities. The outflow of professionals and entrepreneurs from the Pacific Rim region has altered the scene of international migration which used to be dominated by labour migrants. This calls for more sophisticated theories and models to enable us to have a better understanding of the new situation.

The present wave of emigration from Hong Kong has often been characterized as a middle class phenomenon. By developing the notion of network capital, we try to demonstrate the need to revise the conventional class analysis in which property and education are over-emphasized and personal connections are neglected. The fuzzy concept of the middle class should perhaps be replaced with the more precise categories of capitalists, professionals, and entrepreneurs, each pursuing its own distinctive strategies of competition and resource accumulation.

Network capital has its microscopic and macroscopic dimensions. In this paper, we focus on the significance of personal ties and linkages at the individual and family level. When aggregated, such ties and linkages would constitute the collective asset of a society. Seen in this light, the popular alarm about capital flight and brain drain from Hong Kong as a result of the recent outflow of people is probably misplaced. With the multitude of social ties being activated and extended by numerous families in the process of migration, the international linkages of Hong Kong as a node in the global economy are enhanced rather 
than diminished. Yet, as we have indicated in the theoretical discussion, network capital is a mixed blessing fraught with moral ambivalence. In the shadow of the intricate web of overseas linkages lurk popular resentment and hostility among the host communities. That is where the real danger lies for Hong Kong and its emigrants. 


\section{NOTES}

(1) This paper is a product of the research projects on 'Emigration from Hong Kong: Tendencies and Impacts' and 'Emigration from Hong Kong: Families, Networks, and Returnees' funded by the Hong Kong Research Grants Council. Besides the authors, other co-investigators include Daniel Wai-wah Cheung, Yiu-kwan Fan, Kit-chun Lam, Elizabeth Yuk-yee Sinn and Ronald Skeldon. We are grateful to Eric Fong for his contributions to the analysis of the survey data, and to Tak-wing Chan, Katharyne Mitchell, Don Nonini, Aihwa Ong, Mayfair Yang and the two anonymous reviewers for their comments. We thank the following bodies for support: The Hong Kong Research Grants Council; The University Grants Committee of Hong Kong; The Canada-Hong Kong Project, Joint Centre on Asian Pacific Studies, University of Toronto/York University; Initiatives Fund, Institute for International Programs, University of Toronto; and Centre of Urban and Community Studies, University of Toronto. The Department of Sociology and Centre of Asian Studies, University of Hong Kong, gave us on the ground assistance.

(2) We are mainly dealing with informal networks based on kinship or friendship ties in this paper. These personal networks should be distinguished from other types of social networks, such as the more formal intercorporate relations and interlocking directorships, which are known for their capacity in generating economic returns (see e.g. Mizruchi and Schwartz 1987; for a concise overview of social network analysis, see Scott 1991) but with which we are not concerned here. 
(3) For our survey and interviews, we adopt an operational definition of class in terms of occupation. We use only occupation as the indicator of social class partly to avoid cumbersome technical complexities of index construction, and partly because other proxies such as education and income are found to be less reliable for classification purposes in Hong Kong. For a fuller justification, see Salaff and Wong (1994) and Tsang (1994).

In our theoretical discussions, we mainly adopt Max Weber's approach to class analysis by emphasizing the possession of assets which can generate economic returns on the market and affect life chances. As John Scott (1996) points out, the distinction between 'class situation' and 'social class' is fundamental to the Weberian approach. In this paper, we attempt to differentiate among various 'class situations' that consist of specific causal components of life chances. We leave the question of 'social classes', that is, the formation of actual social groupings for collective action, for future analysis (see Lee and Turner 1996 for the recent debate on class analysis). Since the operational definition is used as a classificatory device to guide us in the initial interpretation of the data and we arrive at the analytical definition only at a later stage in the research, the class categories derived from the two definitions do not match completely.

(4) We follow Joseph Schumpeter's definition of entrepreneurs as those who carry out innovations and new combinations of factors of production. In Schumpeter's view, entrepreneurs should be distinguished from capitalists who are owners of money, credit or other material goods. He observes that '[risk] obviously always falls on the owner of the means of production or of the money-capital which was paid for them, hence never on the entrepreneur as such... A shareholder may be an entrepreneur. He 
may even owe to his holding a controlling interest the power to act as an entrepreneur. Shareholders per se, however, are never entrepreneurs, but merely capitalists, who in consideration of their submitting to certain risks participate in profits.' (Schumpeter 1961: 75, original emphases) 


\section{BIBLIOGRAPHY}

Bottomore, T. (ed.) 1983 A Dictionary of Marxist Thought, Cambridge: Harvard University Press.

Bourdieu, P. 1986 'The Forms of Capital' in J. Richarson (ed.), Handbook of Theory and Research for the Sociology of Education, New York: Greenwood Press.

Bourdieu, P. 1987 'What Makes a Social Class? On the Theoretical and Practical Existence of Groups', Berkeley Journal of Sociology 32: 1-17.

Burt, R. 1992 Structural Holes: the Social Structure of Competition, Cambridge: Harvard University Press.

Chu, G.C. and Ju,Y. 1993 The Great Wall in Ruins: Communication and Cultural Change in China, Albany: State University of New York Press.

Cohen, M.L. 1970 'Developmental Process in the Chinese Domestic Group', in M. Freedman (ed.), Family and Kinship in Chinese Society, Stanford: Stanford University Press.

Coleman, J.S. 1988 'Social Capital in the Creation of Human Capital', American Journal of Sociology 94 (Supplement): S95-S120.

Erickson, B.H. 1996 'Culture, Class, and Connections', American Journal of Sociology 102(1): 217-51.

Granovetter, M. 1974 Getting a Job: A Study of Contacts and Careers, Cambridge: Harvard University Press.

Granovetter, M. 1982 'The Strength of Weak Ties: A Network Theory Revisited', in P.V. Marsden and N. Lin (eds), Social Structure and Network Analysis, Beverly Hills: Sage.

Grieco, M. 1987 Keeping It In The Family: Social Networks and Employment Chance, London and New York: Tavistock Publications. 
King, A.Y.C. 1991 'Kuan-hsi and Network Building: A Sociological Interpretation', Daedalus 120(2): 63-84.

Kwong, P.C.K. 1991 'Emigration and Manpower Shortage', in R.Y.C. Wong and J.Y.S. Cheng (eds), The Other Hong Kong Report, 1990, Hong Kong: The Chinese University Press.

Lee, D.J. and Turner, B.S. (eds) 1996 Conflicts About Class: Debating Inequality in Late Industrialism, London and New York: Longman.

Lever-Tracy, C. et al. 1991 Asian Entrepreneurs in Australia: Ethnic Small Business in the Indian and Chinese Communities of Brisbane and Sydney, Canberra: Australian Government Publishing Service.

Luhmann, N. 1979 Trust and Power, Chichester: John Wiley \& Sons.

Mizruchi, M.S. and Schwartz, M. 1987 Intercorporate Relations: The Structural Analysis of Business, Cambridge: Cambridge University Press.

Ong, A. 1992 'Limits to Cultural Accumulation: Chinese Capitalists on the American Pacific Rim', Annals of the New York Academy of Sciences, 645: 125-43.

Poel, M. 1993 Personal Networks: A Rational-Choice Explanation of Their Size and Composition, Lisse: Swets \& Zeitlinger.

Salaff, J.W. and Wong, S.L. 1994 'Exiting Hong Kong: Social Class Experiences and the Adjustment to 1997', in S.K. Lau et al. (eds), Inequalities and Development: Social Stratification in Chinese Societies, Hong Kong: Hong Kong Institute of Asia-Pacific Studies, The Chinese University of Hong Kong.

Schumpeter, J.A. 1961 The Theory of Economic Development: An Inquiry into Profits, Capital, Credit, Interest, and the Business Cycle, Cambridge: Harvard University Press.

Scott, J. 1991 Social Network Analysis: A Handbook, London: Sage Publications. 
Scott, J. 1996 'Class Analysis: Back to the Future?', in D.J.Lee and B.S. Turner (eds), Conflicts About Class: Debating Inequality in Late Industrialism, London and New York: Longman.

Sinn, E. 1995 'Emigration from Hong Kong before 1941: General Trends', in R. Skeldon (ed.), Emigration from Hong Kong, Hong Kong: The Chinese University Press.

Sit, V.F.S. and S.L. Wong 1989 Small and Medium Industries in an Export-Oriented Economy: The Case of Hong Kong, Hong Kong: Centre of Asian Studies, University of Hong Kong.

Skeldon, R. 1990-1 'Emigration and the Future of Hong Kong', Pacific Affairs, 63(4): 50023.

Skeldon, R. (ed) 1995 Emigration From Hong Kong, Hong Kong: Chinese University Press.

Smart, A. 1993 'Gifts, Bribes, and Guanxi: A Reconsideration of Bourdieu's Social Capital', Cultural Anthropology 8(3): 388-408.

Smart, J. and Smart A. 1991 'Personal Relations and Divergent Economies: A Case Study of Hong Kong Investment in South China', International Journal of Urban and Regional Research 15: 216-33.

Sung, Y.W. 1992 'Non-institutional Economic Integration Via Cultural Affinity: The Case of Mainland China, Taiwan and Hong Kong', Occasional Paper No.13, Hong Kong Institute of Asia-Pacific Studies, Hong Kong: The Chinese University of Hong Kong.

Tsang, W. K. 1994 'Behind the Land of Abundant Opportunities: A Study of Class Structuration in Hong Kong', in B.K.P. Leung and T.Y.C. Wong (eds), 25 Years of Social and Economic Development in Hong Kong, Hong Kong: Centre of Asian Studies, University of Hong Kong.

Watson, J.L. 1975 Emigration and the Chinese Lineage: The Mans in Hong Kong and London, Berkeley: University of California Press. 
Wellman, B. and Wortley, S. 1990 'Different Strokes from Different Folks: Community Ties and Social Support', American Journal of Sociology, 96:558-88.

Wong, S.L. 1988 Emigrant Entrepreneurs: Shanghai Industrialists in Hong Kong, Hong Kong: Oxford University Press.

Wong, S.L. 1991 'Chinese Entrepreneurs and Business Trust', in G. Hamilton (ed.), Business Networks and Economic Development in East and Southeast Asia, Hong Kong: Centre of Asian Studies, University of Hong Kong.

Wong, S.L. 1992 'Emigration and Stability in Hong Kong', Asian Survey, 32(10): 918-33.

Wong, S.L. 1994 'Business and Politics in Hong Kong During The Transition', in B.K.P. Leung and T.Y.C. Wong (eds), 25 Years of Social and Economic Development in Hong Kong, Hong Kong: Centre of Asian Studies, University of Hong Kong.

Wong, S.L. 1995 'Business Networks, Cultural Values and The State in Hong Kong and Singapore', in R.A. Brown (ed.), Chinese Business Enterprise in Asia, London and New York: Routledge.

Wong, T.W.P. 1991 'Inequality, Stratification and Mobility', in S.K. Lau et al. (eds), Indicators of Social Development: Hong Kong 1988, Hong Kong: Institute of AsiaPacific Studies, The Chinese University of Hong Kong.

Yang, M.M.H. 1994, Gifts, Favors and Banquets: The Art of Social Relationships in China, Ithaca and London: Cornell University Press.

Zhou, M. 1992 Chinatown: The Socioeconomic Potential of an Urban Enclave, Philadelphia: Temple University Press. 